\title{
Perceived Organizational Support on Employee Performance: The Mediating Effect of Job Stress
}

\author{
Riza Bahtiar Sulistyan ${ }^{1}$, Ratna Wijayanti Daniar Paramita ${ }^{2}$, Moh. Hudi Setyobakti ${ }^{3}$, \\ Noviansyah Rizal ${ }^{4}$, Ninik Lukiana ${ }^{5}$ \\ STIE Widya Gama Lumajang ${ }^{1,2,3,4,5}$ \\ \{rizabahtiars@gmail.com¹,pradnyataj@gmail.com², hudisetyobakti@gmail.com³ \\ noviansyah.rizal@gmail.com ${ }^{4}$, ibundaninik@gmail.com ${ }^{5}$ \}
}

\begin{abstract}
It is very important in supporting employees to be able to develop and advance the organization so that problems related to employee performance can be resolved. In addition, employee performance is closely related to employee stress arising from assigned tasks. This study specifically analyzes models of organizational support and job stress in improving employee performance. A total of 400 employees come from employees of PT. Mustika Buana Sejahtera is willing to be the research sample. The results showed that perceived organizational support was able to reduce employee work stress. However, perceived organizational support cannot directly improve employee performance, but must reduce employee work stress.

Keywords: Perceived Organizational Support, Job Stress, Employee Performance
\end{abstract}

\section{Introduction}

Every organization certainly wants the performance of its human resources to work optimally and have high performance [1]. However, organizations in the world have experienced many changes as a result of the COVID-19 pandemic. This pandemic was completely unpredictable and has even disrupted billions of workers in the world. Of course, the performance of employees in an organization is not optimal [2]. Employee performance in Indonesia during the COVID-19 pandemic has become the center of attention and it is interesting to conduct research such as employee performance in manufacturing companies [3], employees in the medical department [4], in the banking sector [5,6], and financial services [7].

Manufacturing companies have become the center of special attention in the era of the Covid 19 pandemic, especially with over 1000 employees, including PT. Mustika Buana Sejahtera. This company with the largest number of employees in Lumajang Regency, East Java, Indonesia is engaged in wood management and has become the focus of research in recent years [8,9], including related to the use of personal protective equipment [10]. However, there are several factors that still need to be improved related to the performance of employees at PT. Mustika Buana Sejahtera can be more optimal [9]. Employee performance improvement depends on the employee's own circumstances. There are several reasons for the 
sub-optimal increase in employee performance, including because employees experience work stress [11], lack of organizational support [12, 13], lack of employee attachment to the organization [14], and the lack of training programs, so it is necessary to carry out a sustainable development program regularly [15].

Employee performance depends on the employee's own circumstances. The most important thing is to pay attention to the level of employee stress arising from work [9, 11, 16]. High stress levels will reduce employee performance [17]. However, job stress in the form of role ambiguity is not related to employee performance [18]. In addition to work stress being the most important factor in relation to employee performance, organizational support is also the center of organizational attention in shaping optimal employee performance. Perceived organizational support will be able to improve employee performance $[12,13]$. In addition, the organizational support that employees feel can also reduce work stress [19-21]. However, there are also those who say that the existence of organizational support has not been able to reduce employee work stress [22]. In another study also mentioned that perceived organizational support is not related to job stress [23]. In this case, there are still inconsistencies in the results of previous studies related to perceived organizational support, work stress, and employee performance. This study aims to fill the gaps in previous research and examine the perceived organizational support model for employee performance through job stress.

Social exchange theory [24] is used as the basis for this research. This theory refers to the existence of reciprocal behavior that is mutually beneficial between what employees have received from the organization in the form of organizational support and what employees will provide to the organization [21]. The proximity of this theory is useful because of its support [25-30]. This theory has also explained the related returns related to employee performance $[12,31]$. This study designs this theory as the basis for explaining the reciprocal relationship between perceived organizational support and the good performance that employees provide to the company.

The organizational support felt by employees in relation to work stress is designed using organizational support theory [32]. In this theory, it explains the relationship between fellow employees and employees based on social exchange [33]. Organizational support theory in research development has also been applied in research on employee performance [12]. This theory in research is designed to explain the relationship between organizational support felt by employees in reducing work stress, so that employee performance will increase. Previous research, researchers have not found a combination of these two theories in explaining problems in a company related to employee performance related to perceived organizational support with employee work stress.

\section{Method}

This study uses a quantitative approach by looking for causal relationships. It consists of the independent in the form of perceived organizational support, the dependent variable in the form of employee performance, and the intervening variable in the form of job stress. The population was taken from all employees of PT. Mustika Buana Sejahtera, East Java, Indonesia numbered more than 1000 people. The sample used is 400 employees who come from wholesale employees. The sampling technique used a census sample, so that all wholesale employees were taken as respondents. Perceived organizational support is measured by using 3 items [28, 34], namely concern, consideration, and assistance in solving problems. 
Job stress is also measured using 3 items [34, 35], namely role conflict, role ambiguity, and role overload. Employee performance is measured using 5 items [9], namely the ability to work together, quality, quantity, timeliness, and responsibility.

Testing the validity of the research instrument looks at the extent to which the instrument used can be stated as an appropriate measuring tool. By using the criteria for the minimum limit value of the Pearson correlation 0.30. Meanwhile, reliability testing looks at the extent to which the instrument is reliable. The reliability testing criteria can be accepted if the Cronbach's alpha value is more than 0.60. Analysis of direct and indirect effects using SPSS software.

\section{Result and Discussion}

Respondents in this study came from PT. Mustika Buana Sejahtera is part of wholesale employees. The distribution of respondents is based on gender, age and level of education. Judging from the gender, most respondents were male at $86 \%$. It is true that wholesale employees require more male employees than female employees. Based on the age of the respondents, the highest data was obtained, namely those aged between 26 to 30 years (44\%). This age is the productive age desired by the company, while those who are older than that age are partially transferred to another section. The education level of the respondents shows that the largest number of respondents is the high school education level (67.5\%). The results of testing the validity and reliability of the instruments used are presented in the table as follows:

Table 1. The Results of Testing the Validity and Reliability of the Instrument

\begin{tabular}{lccc}
\hline \multicolumn{1}{c}{ Indicator Variable } & Pearson Correlation & Cronbach's Alpha & Information \\
\hline Perceived Organizational Support (POS) & & 0.770 & Reliable \\
Concern & 0.821 & & Valid \\
Consideration & 0.860 & & \\
Help solve problems & 0.812 & 0.615 & Reliable \\
Job Stress (JST) & & & Valid \\
Role conflict & 0.745 & & \\
Role ambiguity & 0.722 & \multirow{2}{*}{0.810} & Reliable \\
Role overload & 0.787 & & Valid \\
Employee Performance (EPR) & & & \\
Cooperate & 0.788 & & \\
Quality & 0.776 & & \\
Quantity & 0.769 & & \\
On time & 0.800 & & \\
Responsible & 0.632 & & \\
\hline
\end{tabular}

Source: Data processed in 2020

The instrument from each variable shows that the overall value of the Pearson correlation is more than 0.30 so it can be concluded that the instrument is an appropriate or valid measuring tool. Judging from the Cronbach's alpha value, it shows that the three variables are worth more than 0.60 , so it can be concluded that the instrument of the three variables is reliable or reliable. The results of testing the direct and indirect effects can be seen in the following figure. 


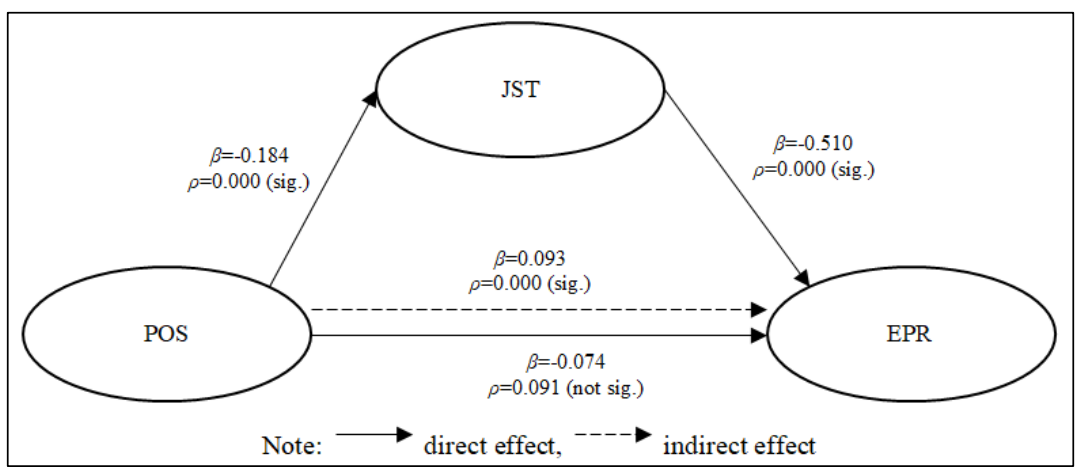

Fig. 1. Direct and Indirect Effect

Source: Data processed in 2020

From the test results in Figure 1 shows that perceived organizational support has a negative and significant effect on job stress $(\beta=-0.184, \rho=0.000)$. These results indicate that the higher the perceived organizational support, the lower the job stress will be. Job stress has a negative and significant effect on employee performance $(\beta=-0.510, \rho=0.000)$, meaning that the higher the job stress of the employee, the lower the employee performance. However, perceived organizational support did not have a significant effect on employee performance ( $\beta$ $=-0.074, \rho=0.091)$. Perceived organizational support will affect employee performance if it is through job stress $(\beta=0.093, \rho=0.000)$. In this case, the higher the perceived organizational support, the lower the job stress and later it will increase employee performance.

\subsection{Perceived Organizational Support and Job Stress}

The organizational support felt by employees of PT. Mustika Buana Sejahtera is high, will be able to reduce the level of work stress of its employees. These results support previous studies which show that perceived organizational support can reduce employee work stress $[9$, $11,16,17]$. There are other studies that are not in accordance with the results of this study which states that high organizational support is not able to reduce work stress [22, 23]. The organizational support felt by employees in overcoming work stress levels is in accordance with organizational support theory $[32,33]$.

This result is inseparable from the fairly high value of the respondents for each of the assessment indicators. There is a main priority from the results of the assessment, namely the support from the organization in the form of assistance to solve employee problems. The assistance provided by the company is manifested not only in the form of assistance in solving work problems, but also in solving personal problems. Help to solve problems like this can reduce employee work stress. Work stress in the form of role conflict can be overcome from the assistance to solve work-related problems and personal problems in the family. Another form is the ambiguity of roles in work which can arise from the absence of assistance to solve problems from the company. This assistance is needed so that employees do not feel ambiguous in their position when completing work. Help solving problems will be very valuable in the company when employees experience excess roles. This excess role is an indication of work stress from employees.

The second priority, organizational support in the form of consideration of input from subordinates. The existence of considerations like this is important in dealing with employee 
work stress. Consideration in terms of expressing opinions has been able to reduce work stress from employee role conflicts. The emotional level of employees can be lowered through discussions with the company and considering opinions or complaints during their work. Fair consideration of the delivery of employee opinions to the organization is also able to reduce the level of employee role ambiguity. Employees do not feel ambiguous in their work and feel fair in their treatment. Consideration of the input or opinion that the company has made to employees is also able to reduce the burden on employees from the perceived excess role. The excess role that employees perceive will be conveyed to the company, because employees are not afraid to express their opinions and feel proud if their opinions can be considered.

The last priority is concern from the company to employees. This concern is manifested in several forms, such as caring if employees have a work accident, caring about the opinions of employees, and caring about the facilities and infrastructure used by employees in completing work. This form of caring is able to reduce the level of role conflict, because employees do not feel there is injustice at work. The concern given by the company is also able to reduce the level of ambiguity of employee roles. Employees are more focused on completing work and confusion which has been felt to be minimized. High concern will be able to reduce the feelings of employees who experience excess roles.

\subsection{Perceived Organizational Support and Employee Performance}

Organizational support that is felt directly has not been able to improve the performance of the employees of PT. Mustika Buana Sejahtera. Even though the support provided is very high, the employee's performance will remain as usual. This result is not in accordance with previous research which states that the higher the perceived organizational support, the higher the employee's performance will be $[12,13]$. Social exchange theory in this study has not been able to explain the relationship between perceived organizational support and employee performance.

Perceived organizational support is indicated by the help to solve problems, considerations, and concerns. The main priority is assistance in solving problems faced by employees, but have not been able to increase employees in working together to complete work. Employees already have a good form of cooperation between fellow employees and also leaders. This assistance has also not been able to improve the quality and quantity of employee work. The quality of employee work has been properly monitored and measured, so that the quality of employee work will run properly and not due to organizational support in the form of assistance in solving problems. The quantity of employee work also does not affect the assistance in solving problems. There are targets that must be met by each employee, so that employees work according to the target and work quantity will also be maintained. In addition, the assistance provided by the company in solving problems does not have an impact on the timeliness of employees in completing work. Employees work on time due to other factors such as salary. As a wholesale employee, the faster they complete the job, the more work they will be able to do. Assistance in completing work does not make employees more responsible. This is because the wholesale employees have carried out their work according to their responsibilities.

The existence of consideration in accommodating employee input becomes the second priority. However, it cannot improve employee performance in the form of increased cooperation, quality of work, quantity of work, timeliness, and responsibility. Consideration of the opinions of subordinates does not lead to increased cooperation between employees in completing work. Employee cooperation has been going well, not on the basis of 
consideration of their opinions. The consideration has also not been able to improve the quality and quantity of employee work. Good quality has been shown from the wholesale employees. The quantity is also like that, all the targets which are the quantity of each employee have been met. The quality and quantity are basically formed not based on the opinion of employees, but on other factors. Consideration of opinion or input is not the basis for employees to complete work on time. Wholesale employees are on time at work and it is proven by an assessment of the timeliness of the company. The consideration given by the company for input from employees does not affect the increase in responsibility. The responsibility of wholesale employees can be said to be good, because the form of responsibility can be proven from each work that has been completed.

The form of concern for employees is the last priority of the indicators of organizational support that employees feel. Concern with respect to work, is given to employees in the form of caring about employee problems, both internal and external, as well as caring when employees have a work accident. Concern like this does not guarantee that employee employees can improve their performance in the form of good cooperation between employees. Despite the high concern given by the company, cooperation between fellow employees will run properly. High concern also has not been able to improve the quality and quantity of employee work. The quality of work for wholesale employees is good and does not require any caring factors from the company. Likewise with the quantity of work, piece employees have indeed shown a good quantity of work and not from the care given by the company. The existence of concern from the company to the employees is not related to the timeliness and responsibility of the wholesale employees. Wholesale employees are on time in completing work and not on the basis of concern from the company. Likewise, the high responsibility of each employee has been shown. This is not due to the high concern that the company gives to employees.

\subsection{Job Stress and Employee Performance}

High job stress can reduce employee performance. Conversely, when employee work stress decreases, employee performance will increase. These results are consistent with previous studies which show that job stress has a negative effect on employee performance $[9$, $11,16,17]$. However, these results are not in accordance with previous studies which show that job stress in the form of role ambiguity is not able to improve performance [18]. The results of this study support organizational support theory [32,33] in explaining organizational support so as to reduce employee work stress and will be able to improve employee performance.

Role conflict, role ambiguity, and role overload are indications of employee job stress. Of the three indications, role ambiguity is a top priority in job stress as assessed by part-time employees of PT. Mustika Buana Sejahtera. High role ambiguity will cause a decrease in employee performance in the form of cooperation between employees. Employees who feel ambiguous in job roles, most of their performance decreases. They are confused on which position to work so that good cooperation decreases when things happen. Role ambiguity also reduces the quality and quantity of employee work. The quality of employee work decreases when the work stress increases. Likewise, the quantity of employee work will decrease when the ambiguity of the employee's role increases. The existence of this ambiguity can reduce employee performance in the form of timeliness and responsibility. Punctuality decreases further when employees feel ambiguous about where they are working. In addition, 
responsibilities will also be ambiguous when they are in an unclear position, so that employee responsibilities decrease.

The second priority of job stress is role overload. The advantages of the role given by the company can reduce employee performance in the form of cooperation, quality and quantity of work, punctuality, and responsibility. So far, employees have worked well together among their fellow employees, but this will decrease when there is an increase in excess roles. Likewise, the quality of work of employees that has been good so far will decrease when there is excess role. The more roles that are given, the lower the quality of work will be. Because there is a limit to the ability of what employees do and checking the quality of work is not optimal from the internal side of the employee itself. The quantity of employee work will also decrease when there is an increase in excess roles. There are limitations to employees in completing work per day, so that when the role is excessive, the quantity will decrease. High role excess will reduce the level of timeliness of employees in completing work. Employees who initially are on time to complete work will not be on time when there is an increase in excess roles. The final impact of the existence of excess roles is a decrease in responsibility. A good responsibility will become uncontrollable when the role is added and has excess.

The last priority of job stress is role conflict. This role conflict needs to be a concern which will have an impact on employee performance decline in the form of cooperation between employees, work quality, work quantity, timeliness, and responsibility. High role conflict will change the cooperation that is already running well. Cooperation between fellow employees in completing work will decrease when role conflicts occur. The existence of role conflicts will also reduce the quality and quantity of employee work. Good work quality of employees has been proven by the results of work in accordance with predetermined standards. When there is a role conflict, it will have an impact on quality degradation. Likewise with the quantity of employee work which has been in accordance with the target set by the company. High role conflict will result in employee timeliness and decreased responsibilities. All this time, employees have been on time, but it has been proven from the role conflict that has arisen that makes them often miss work. Responsibilities that have been good so far will also experience problems when role conflicts continue to occur in employees.

\subsection{Perceived Organizational Support, Job Stress and Employee Performance}

Organizational support that is felt is not able to directly improve employee performance. This is not in accordance with the concept of social exchange theory [24, 25]. However, the perceived organizational support will be able to increase the ability to improve employee performance by reducing work stress. High organizational support for employees can reduce work stress, so that employee performance will increase. In accordance with the concepts that have been formed using organizational support theory [32, 33]. Wholesale employees of PT. Mustika Buana Sejahtera has felt the support of the organization that has been provided in the form of assistance in solving problems, consideration of employee opinions, and the high concern of the company for employees. This turned out to be able to reduce the level of employee work stress in the form of role ambiguity, role overload, and role conflict. After the work stress decreases, the wholesale employee performance will increase. Performance is shown by the existence of good cooperation among fellow employees, good quality of work, quantity of work according to targets, timeliness of employees in completing work, and the existence of a form of employee responsibility at work. 


\section{Conclusion}

The organizational support felt by employees of PT. Mustika Buana Sejahtera is able to reduce employee work stress levels. A reduction in employee work stress will improve employee performance. However, organizational support that is felt is not able to directly improve employee performance. What is unique is that organizational support is felt to be able to improve employee performance if the organizational support reduces employee work stress first. These results are in accordance with organizational support theory where there is support to reduce employee work stress so that performance can increase.

Social exchange theory is related to perceived organizational support which is not able to explain directly in improving employee performance. This is because employee performance is already good and a decrease or increase in employee performance only occurs when employees experience stress at work.

\section{References}

[1] Sulistyan, R.B., Kondisi Lingkungan Pekerjaan Sebagai Ukuran Kesetiaan Pada Organisasi. WIGA : Jurnal Penelitian Ilmu Ekonomi, 2018. 8(1): p. 32-41.

[2] Sanders, K., et al., Unraveling the What and How of Organizational Communication to Employees During COVID-19 Pandemic: Adopting an Attributional Lens. The Journal of Applied Behavioral Science, 2020. 56(3): p. 289-293.

[3] Abdallah, The Effect Of Corona Pandemic OnWorkers' Psychology And Performance In The Manufacturing Sector. Systematic Reviews in Pharmacy, 2020. 11(12): p. 15931599.

[4] Qomariah, N., et al., How to Improve Employee Performance at Level 1 Health Facilities During the Covid 19 Pandemic? International Journal of Engineering Research and Technology, 2020. 13(9): p. 2511-2518.

[5] Sembiring, M.J., et al., Banking Employee Performance During Pandemic Covid-19: Remuneration And Motivation. Journal of Xi'an University of Architecture \& Technology, 2020. 12(7): p. 64-71.

[6] Rahman, M.F.W., A. Kistyanto, and J. Surjanti, Flexible Work Arrangements in Covid19 Pandemic Era, Influence Employee Performance: The Mediating Role of Innovative Work Behavior. International Journal of Management, Innovation \& Entrepreneurial Research, 2020. 6(2): p. 10-22.

[7] Adhitama, J. and S. Riyanto, Maintaining Employee Engagement and Employee Performance during Covid-19 Pandemic at PT Koexim Mandiri Finance. Journal of Research in Business and Management, 2020. 8(3): p. 6-10.

[8] Khomar, A.P. and R.H. Mustamu, Penerapan Succession Plan pada Perusahaan Keluarga di Bidang Perkayuan. AGORA, 2014. 2(1): p. 467-472.

[9] Ghofur, A., R.B. Sulistyan, and J. Irwanto, Dampak Stres Kerja, Lingkungan Kerja Terhadap Kinerja Karyawan Perusahaan pada PT. Mustika Buana Sejahtera di Lumajang. Jobman: Journal of Organization and Business Management, 2020. 2(2): p. 89-94.

[10] Dewantara, B.P., B. Murti, and V. Widyaningsih, Application of Health Belief Model and Social Cognitive Theory on the Use of Personal Protective Equipment among Workers at the Plywood Plant: Path Analysis Evidence from Lumajang, East Java. Journal of Health Promotion and Behavior (2019. 4(4): p. 306-318. 
[11] Undie, U.P., S.I. Ukpata, and A.S. Iyortsuun, Job Stress and Employee Performance in the Nigerian Banking Sector. International Journal of Modern Management Sciences, 2018. 7(1): p. 40-51.

[12] Chen, T., et al., The impact of organizational support on employee performance. Employee Relations: The International Journal, 2020. 42(1): p. 166-179.

[13] Ridwan, M., S. RizkiMulyani, and H. Ali, Improving Employee Performance Through Perceived Organizational Support, Organizational Commitment and Organizational Citizenship Behavior. Systematic Reviews in Pharmacy, 2020. 11(5): p. 839-849.

[14] Anitha, J., Determinants of employee engagement and their impact on employee performance. International Journal of Productivity and Performance Management, 2014. 63(3): p. 308-323.

[15] Elnaga, A. and A. Imran, The Effect of Training on Employee Performance. European Journal of Business and Management, 2013. 5(4): p. 137-147.

[16] Prasad, K.D.V., R. Vaidya, and V.A. Kumar, Association among Occupational Stress factors and Performance at workplace among Agricultural Research Sector Employees at Hyderabad, India. Pacific Business Review International, 2018. 10(7): p. 27-36.

[17] Yunita, P.I. and I.G.N.W.H. Saputra, Millennial generation in accepting mutations: Impact on work stress and employee performance. International Journal of Social Sciences and Humanities, 2019. 3(1): p. 102-114.

[18] Jalagat, R., Determinants of Job Stress and Its Relationship on Employee Job Performance. American Journal of Management Science and Engineering, 2017. 2(1): p. $1-10$.

[19] Arnold, R., T. Edwards, and T. Rees, Organizational stressors, social support, and implications for subjective performance in high-level sport. Psychology of Sport and Exercise, 2018. 39: p. 204-212.

[20] Pinto, R.J., et al., Psychological Distress and Posttraumatic Stress Symptoms. Journal of Interpersonal Violence, 2016: p. 088626051667419.

[21] Sulistyan, R.B., et al., Retention Management as an Effort to Overcome the Intention of Account Officers to Stop the Company. Journal of Advanced Research in Dynamical and Control Systems, 2019. 11(12): p. 17-25.

[22] Gökçearslan, Ş., Ç. Uluyol, and S. Şahin, Smartphone addiction, cyberloafing, stress and social support among university students: A path analysis. Children and Youth Services Review, 2018. 91: p. 47-54.

[23] Garg, S. and R.L. Dhar, Effects of stress, LMX and perceived organizational support on service quality: Mediating effects of organizational commitment. Journal of Hospitality and Tourism Management, 2014. 21: p. 64-75.

[24] Blau, P.M., Exchange and power in social life. 1964, New York: Wiley.

[25] Roloff, M.E., Social Exchange Theories. The International Encyclopedia of Interpersonal Communication, 2015: p. 1-19.

[26] Sulistyan, R.B., Lecturer E-learning Training: The Role of Social Exchange Theory. Empowerment Society, 2020. 3(2): p. 50-56.

[27] Mishra, P., et al., How work-family enrichment influence innovative work behavior: Role of psychological capital and supervisory support. Journal of Management \& Organization, 2019. 25(1): p. 58-80.

[28] Yildiz, B., S. Uzun, and S.S. Coşkun, Drivers of innovative behaviors: The moderator roles of perceived organizational support and psychological empowerment. International Journal of Organizational Leadership, 2017. 6: p. 341-360. 
[29] Wong, Y.-W. and Y.-t. Wong, The effects of perceived organisational support and affective commitment on turnover intention. Journal of Chinese Human Resources Management, 2017. 8(1): p. 2-21.

[30] Kim, H.J., et al., Is all support equal? The moderating effects of supervisor, coworker, and organizational support on the link between emotional labor and job performance. BRQ Business Research Quarterly, 2017. 20(2): p. 124-136.

[31] Roberts, J.A. and M.E. David, Boss phubbing, trust, job satisfaction and employee performance. Personality and Individual Differences, 2020. 155: p. 109702.

[32] Eisenberger, R., et al., Perceived Organizational Support. Journal of Applied Psychology, 1986. 71(3): p. 500-507.

[33] Baran, B.E., L.R. Miller, and L.R. Shanock, Advancing Organizational Support Theory into the Twenty-First Century World of Work. Journal of Business and Psychology, 2011. 27(2): p. 123-147.

[34] Sulistyan, R.B. and E. Ermawati, Explaining Cyberloafing Behavior: The Role of General Strain Theory. Wiga : Jurnal Penelitian Ilmu Ekonomi, 2020. 10(2): p. 148156.

[35] Kang, S.-W. and S.-D. Kang, High-Commitmen Human Resource Management and Job Stress: Supervisor Support as a Moderator. Social Behavior and Personality, 2016. 44(10): p. 1719-1732. 